Website: ijetms.in Issue: 2 Volume No.5 March - 2021 DOI: 10.46647/ijetms.2021.v05i02.001

ISSN: 2581-4621

\title{
Status of Women-entrepreneur in Indian Startups
}

\author{
Narendra Kumar*, Dr. L. K. Singh*, \\ *Department of Management Studies, Kumaun University, Bhimtal, Nainital, India
}

narendr. kumba@gmail. com

\begin{abstract}
Entrepreneurship refers to the process of creating wealth for the society with the entrepreneurial capability not only for the entrepreneur but also for the societal, government, and economy of nation cause by availing the opportunities in a fast-shifting social, political, legal and economic environment. The increasing rate of Start-ups has been registered over a couple of years and in maximum start-ups founders are male. Female entrepreneur is now initiating and performing at the digital platform. Females increasing number of enrolment in schools and higher education has contributed to innovative products and niche market.
\end{abstract}

Women play a vital role in every sphere of life in the family and in building society as well. As far as an entrepreneur is concern there is insignificant participation of women entrepreneurs. In the 21 st century, as women empowerment has become the main focus of discussion, the government and societies have identified the potentially women's participation and their importance but still while creating policies women entrepreneur is ignored. The participation of women is necessary for socio-economic progress and for the large interest of any Nation. Strategy makers must understand the prerequisite for women entrepreneurs and avenues for women's economic independence.

The Government of India has defined women entrepreneurs as "An enterprise owned and controlled by women having a minimum financial interest of 51 per cent of the capital and giving at least 51 per cent of the employment generated in the enterprise to women. Women Entrepreneur is a person who accepts a challenging role to meet her personal needs and become economically independent." This study analyses their current status causes that have provoked them to set free their entrepreneurial abilities into start-ups. The study will facilitate in understanding the women-entrepreneurship to researchers, policy-makers, educators and practitioners help them to foster a favourable conducive ecosystem for women-entrepreneur. This research study is based on secondary data where drawbacks in entrepreneurial policy are highlighted and some recommendations are given to promote the healthy growth of women entrepreneurs.

As per scheme guidelines, in Entrepreneurship Awareness Programme (EAP) and Entrepreneurship Skill Development Programme (ESDP) there should be overall $40 \%$ women participation.

This paper tries to analyze the participation of women startups in economic development and to identify various factors responsible for higher numbers of womenstartups.

The causes of low female-start-up participation are difficult in access to finance and networks, responsibilities towards family and child-care, low level of confidence in business in women's skills. This research paper tries to recommend some measures that can assist women's entrepreneurial empowerment. This study also gives an insight into opportunity and prospect for female-entrepreneur and analyse start-up scheme of government to empower women entrepreneurs and the challenges they face.

Keywords: Women entrepreneurs, Startup Policy, Challenges for women entrepreneur. 


\section{International Journal of Engineering Technology and Management Sciences}

Website: ijetms.in Issue: 2 Volume No.5 March - 2021 DOI: 10.46647/ijetms.2021.v05i02.001 ISSN: $2581-4621$

\section{INTRODUCTION}

An entrepreneur plays a crucial function in the development of society. Growth of entrepreneurial customs and sustainable business are needs for the growth of the economy. Entrepreneurship development act as a catalyst in developing key element in strategies that allows economies to benefit from the talents, energy, and ideas.

A large gap still exists among the goals mentioned in the Constitution, legislation, policies, and the situational truth of women in India. (National Policy for the Empowerment of Women (2001)).

Entrepreneurship is an individual's imaginative courage for generating jobs, wealth creation, and social welfare. Women entrepreneurs are fundamental for the transformation of industrialization and expulsion of various social and other issues like unemployment and women exploitation. At present, there are at least two or three female in every family but the role and the position of female and mindset towards women is still similar to preindependence. Women are now having

\section{OBJECTIVES OF THE STUDY:}

1. To create awareness and analyze the present status of Women Entrepreneurs in India.

2. To assess the factors initiated by different institutions for encouraging women.

3. To critically examine the challenges faced by women entrepreneurs.

4. Suggesting key input for effective policymaking for improving women entrepreneurs.

\section{RESEARCH METHODOLOGY:}

prominent participation in almost every field. But still, their involvement in entrepreneurial activities is negligible. Women entrepreneurs are an emerging economic force, which should not be ignored by the policymakers. The world's modern democratic economy depends on the participation of both genders.

Women entrepreneur contribution in revenue-generating activities is relatively disappointing India, which is only eight percent of the small scale- manufacturing units whereas women in developed economies own about more than 25 percent in revenue-generating activities.

Over the past decade, women around the world have made substantial improvements in health and education, politics, and other areas. It is taking place at a time while entrepreneurship is recognized as crucial to economic development and sustainability globally. In order to assess and understand the scale, scope, practices, and impact of women's entrepreneurship. A longitudinal study is conducted by the Global Entrepreneurship Monitor research consortium from 2012-2014 where about 73 countries participated.

This research study is based on secondary data collected from Census Surveys, books, SSI Reports, newspapers, magazines, journals, etc.

\section{IMPORTANCE OF WOMEN ENTREPRENEURSHIP:}

Women entrepreneurs play an imperative function in constructing the backbone of a nation's economy. People, time management, and family budgeting are women's skills that can be channelized in the business environment. Women have efficient in balancing diverse tasks and maintaining customers' and employees' relationships. 


\section{International Journal of Engineering Technology and Management Sciences}

Website: ijetms.in Issue: 2 Volume No.5 March - 2021 DOI: 10.46647/ijetms.2021.v05i02.001 ISSN: $2581-4621$

The process of economic development would be partial and unbalanced, until and unless women are fully participating in it. The orientation of a society towards women is a very vital prerequisite for the advancement of the country. The financial status of a woman is now understood as an indicator of society's development phase.

\section{STATUS OF WOMEN ENTREPRENEURS}

According to Global Entrepreneurship Research Association, London Business School, London, The Global Entrepreneurship Monitor (GEM) 2016/ 2017 Women's Report provides valuable insight for policy decision making, Designing initiatives and programs, and future research in this critical area. Women-entrepreneurs are catching-up. Total Entrepreneurial Activity among women was $7 \%$ in 2013-14 which increased to $10 \%$ in 2015-16. The gender gap decreased by $6 \%$ in 2013-14 and which gain narrowed by $5 \%$ in 2015-16.

Women's participation in entrepreneurship varies greatly across the world, from $3 \%$ in Germany, Jordan, Italy, and France to $37 \%$ in Senegal. In Jordan, men are 4 times more likely than women to start a business. women are one third more likely than men to start a business in Vietnam,. In fact, the rate of women entrepreneurs matches or exceeds that of men in only 5 (five) out of 74 Nations; Brazil, Indonesia, Mexico, Philippines, Vietnam.

Studies have shown that in India women's work contribution is low as compared to the rest of the counties in the world. Women's work participation in India is 31.6 $\%$ whereas in the USA it is $45 \%$, UK $43 \%$, Canada $42 \%$, France $32 \%$, Indonesia $40 \%$, Sri Lanka, and Brazil both $35 \%$.
In India, generally, men initiate in the entrepreneurial world. With the course of time and changing cultural norms and an increase in literacy rate, women in Indian are accepting entrepreneurship as their career. With the initiative and active involvement of media, women are becoming aware of their rights and policies. They are flourishing their entrepreneurial career as designers, interior decorators, exporters, publishers, garment manufacturers and still exploring new avenues for economic contribution.

\section{WOMEN ENTREPRENEURSHIP IN INDIA}

Women's involvement in economic activity is common from very long ago. There have been several transitions in the role of women which took centuries to move in the current position. Indian Women entrepreneurship in India has explored a new ideology of economic contribution by participating in diverse sectors and managing the industries.

Women in India entered the industry due to pull and push factors with full of challenges, like Male-dominated society, Problem of finance, Limited mobility, Legal formalities, Exploitation by middlemen, underestimated, Lack of information regarding the resources. Even after having lots of hurdles, many women have proved themselves independent and flourishing entrepreneurs. The emergence of women entrepreneurs and their important contributions to the nation are visible and these businesses are equipped for sustained growth prospects. Women comprise half of the total population (495.74 million) in India, but their contribution to economic activity is negligible. The Female work-sharing rate was 25.7 percent in 2001 . 


\section{International Journal of Engineering Technology and Management Sciences}

Website: ijetms.in Issue: 2 Volume No.5 March - 2021 DOI: 10.46647/ijetms.2021.v05i02.001 ISSN: 2581-4621

\section{VII.PARTICIPATION OF WOMEN IN THE SSI SECTOR IN INDIA}

Women's participation in the SSI sector has been recognized as owners, as managers, and as employees. Kerala had the largest number of units managed by women $(1,37,561)$ and women.

\begin{tabular}{|c|c|c|c|}
\hline & Year & $\begin{array}{l}\text { Number of } \\
\text { Self- } \\
\text { employed } \\
\text { women }\end{array}$ & $\begin{array}{l}\text { Percentage of } \\
\text { the total Self- } \\
\text { employed } \\
\text { persons in } \\
\text { India. }\end{array}$ \\
\hline 1 & $\begin{array}{l}1981 \\
\text { census }\end{array}$ & $1,50,000$ & $5.2 \%$ \\
\hline 2 & $1988-89$ & $\begin{array}{l}\text { more than } \\
1,53,260 \\
\text { women }\end{array}$ & $\begin{array}{l}9.01 \% \text { of the } \\
\text { total } \\
\text { million } \\
\text { entrepreneurs }\end{array}$ \\
\hline 3 & $1995-96$ & $2,97,696$ & $11.2 \%$ \\
\hline 4 & $\begin{array}{l}2001- \\
2002\end{array}$ & $10,63,721$ & $10.11 \%$ \\
\hline
\end{tabular}

\section{INSTITUTIONAL}

LEVEL POLICY INITIATIVES IN PROMOTING WOMEN STARTUps IN INDIA:

The ultimate aim of policies is to foster an environment that encourages women participation in entrepreneurship as a possible career alternative, equips them with the tools to create a quality of business and creates knowledge among stakeholders who will maintain their efforts.

\section{(I) Government initiatives for development of Women-Startups}

a. Since independence women's development has been a mission for the government. Health, education, and employment were always areas of attention early 80's. Women are given preference in all the sectors. Government and other agencies have regularly put efforts to increase women's involvement through selfemployment and industrial ventures.

b. In the First Five-Year Plan (1951-56) some welfare schemes for women were initiated Central Social Welfare Board (CSWB), Mahila-Mandals and the Community Development Programmes (CDP).

c. In the second Five-Year Plan (195661 ), the women-empowerment policies were closely linked with the agricultural development programs.

d. In the Third and Fourth Five-Year Plans (1961-66 \& 1969-74) encouraged female education as a primary welfare measure.

e. In the Fifth Five-Year Plan (1974-79) gave priority to women training, who were in need of income and protection. Women's welfare and Development Bureau (WWDB) was set up in1976, under the Ministry of Social Welfare.

f. In the Sixth Five-Year Plan (1980-85), it was found that women's growth is poor due to lack of access to resources and there was a shift from welfare to development. 


\section{International Journal of Engineering Technology and Management Sciences}

Website: ijetms.in Issue: 2 Volume No.5 March - 2021 DOI: 10.46647/ijetms.2021.v05i02.001 ISSN: 2581-4621

g. The Seventh Five-Year Plan (1985-90) identified the need for gender equality and women empowerment. Emphasis was given to the generation of awareness and confidence through training in skill development.

h. In the Eighth Five-Year Plan (1992-97) Panchayati Raj Institutions was introduced which was inclined on women-empowerment at the Grass Roots Level.

i. A strategy of Women's Component Plan was adopted in the Ninth FiveYear Plan (1997-2002) under which not less than 30 percent of funds/ benefits were earmarked for women related sectors.

j. With an aim of empowering women, in the Tenth Five-Year Plan (2002-07) the National Policy for Women Empowerment (2001)was put into action and to ensuring their Survival, Security and Development.

k. During (2007-12) Government found that at least 33 percent of all beneficiaries of all government schemes were women and Girl children. Support to Training \& Employment Programme for Women STEP provides training for skill development to weak and assetless women in traditional sectors of agriculture, animal husbandry, dairy, fisheries, handlooms, handicraft, Khadi and village industries, sericulture.

1. In framing policies/schemes for the Twelfth Five Year Plan (2012-17) the Mahila Kisan Sashaktikaran Pariyojana (MKSP) which is a sub-component of National Rural Livelihood Mission (NRLM) was launched to meet the specific needs of women farmers, and help them achieve social, legal, economic and technical empowerment.

Civil society's efforts for development of women-startups

Civil society's increasing involvement in the process of women's empowerment.

a. Implementing program or facilitating agencies at the grassroots;

b. Providing training to women and to government staff in women's programs; working with the State and central governments and commercial banks in pilot projects;

c. Doing field research, providing feedback and critiquing policies.

(II) Financial Institutions Assisting female-startups in India

For several years, financial institutions have been playing a critical role in giving financial support and consultancy services to womenentrepreneurs. These institutions include:

1. National Small Industries Corporation (NSIC),

m. All-India Development Banks (AIDBs), viz. IDBI, IFCI, ICICI, IIBI, IDFC and SIDBI,

n. Specialized Financial Institutions (SFIs), viz. EXIM Bank and NABARD,

o. Investment Institutions, viz. LIC, GIC, NIC, NIA, OIC, UII and UTI,

p. Regional/ State-Level Institutions, viz. NEDFI (North Eastern Development Finance Corporation), SIDCs and SFCs, 


\section{International Journal of Engineering Technology and Management Sciences}

Website: ijetms.in Issue: 2 Volume No.5 March - 2021 DOI: 10.46647/ijetms.2021.v05i02.001 ISSN: $2581-4621$

q. Commercial Banks,

r. Co-operative Banks, etc.

(III) Other Women Entrepreneurs Associations Include:

a. Federation of Indian Women Entrepreneurs (FIWE) - It was founded in 1993 as a result of the International Conference of Women Entrepreneurs. They interact with various women's associations in the country to facilitate.

b. Khadi and Village Industries Commission (KVIC) - as a statutory organization engaged in providing employment opportunities in rural areas for women entrepreneurs.

c. Micro, Small and Medium Enterprises Development Organisation (MSME-DO) - It is the apex body for assisting the Government in formulating, coordinating, implementing and monitoring policies and programs in the country. MSME-DO facilitates technology support services, marketing assistance, entrepreneurial development support among others, to women entrepreneurs.

d. National Bank for Agriculture and Rural Development (NABARD) NABARD is an autonomous financial institution that provides liberal credit to rural women entrepreneurs.

e. International Centre for Entrepreneurship and Career Development (ICECD) - it has been involved in training women entrepreneurs for MSME development on large scale over the last 25 years. It has extended its operations internationally and supported women entrepreneurs in over 55 countries.

f. National Resource Centre for Women (NRCW)

Under the National Commission for Women Act, 1990 NRCW was set up to orient and sensitize policy planners towards women's issues, facilitating leadership training and creating a national database in the field of women's development.

g. Women's India Trust (WIT)

In 1968 WIT was established to develop skills of women and to earn a regular income by providing training and employment opportunities to the deprived and untrained women of all communities around Mumbai.

h. Women Development Corporation (WDC)

WDCs were set up in 1986 to generate continuous incomegenerating activities for women to provide better employment opportunities for women so as to make them economically independent.

i. Development of Women and Children in Urban Area (DWCUA) In 1997 DWCUA was set up to organize the urban poor women in socio-economic self-employment activity groups with the objective of providing self-employment opportunities and social strength to them. 


\section{International Journal of Engineering Technology and Management Sciences}

Website: ijetms.in Issue: 2 Volume No.5 March - 2021 DOI: 10.46647/ijetms.2021.v05i02.001 ISSN: 2581-4621

j. Association of Women

Entrepreneurs of Karnataka (AWAKE)

AWAKE was constituted by a team of women entrepreneurs in Bangalore with a view to helping other women in different ways -to plan project reports, to secure investment, to choose and use a product, to deal with bureaucratic hassles, to deal with labor inconvenience, etc.

k. Working Women's Forum (WWF) WWF was formed in Chennai for the progress of deprived working women to save small traders from the interruption of middlemen and to make them confident entrepreneurs in their own right. The women engaged in fisherwomen, lace makers, beedi making women, landless women, laborers, and agarbathi workers are beneficiaries.

1. Women's Occupational Training Directorate

Regular skill training courses at basic, advanced and most advanced levels are organized. There are about 10 Regional Vocational Training Institutes (RVTIs) in different parts of the country, besides a National Vocational Training Institute (NVTI) at NOIDA.

m. Aid The Weaker Trust (ATWT)

ATWT was constituted in Bangalore to impart training to women in printing. It is the only one in Asia which beneficial for women all over Karnataka. It provides financial support and equips girls with proficiency in diverse aspects of printing and building up selfconfidence.

n. Self- Employed Women's Association (SEWA)

SEWA is a trade union of poor selfemployed women workers registered in 1972

o. Women Entrepreneurship of Maharashtra (WIMA)

It was set up in 1985, provides training to its members. It was established industrial estates in New Mumbai and Hadapsar.

p. Self- Help Group (SHG)

An association of women, formed for the purpose of elevating the women belonging to the Below Poverty Line (BPL). Income generation programs, informal banking, credit, unions, health, nutritional programs, etc the major activities of the group.

q. The National Resource Centre for Women (NRCW)

An independent body set up to sensitize policy planners towards women's issues and creating a database of women's development.

r. Women Development Cells (WDC) NABARD has been supporting the setting up of Women Development Cells (WDCs) to rationalize gender growth in Regional Rural Banks and Cooperative Banks. 


\section{International Journal of Engineering Technology and Management Sciences}

Website: ijetms.in Issue: 2 Volume No.5 March - 2021 DOI: 10.46647/ijetms.2021.v05i02.001 ISSN: 2581-4621

\section{EXISTING POLICIES FOR}

\section{ENTERPRISE DEVELOPMENT}

After assessing the policies and the way they implemented on women enterprises, the policies can be classified under the following headings:

Various policies of MSME for women's entrepreneurship development play a prime role.

1. Regulatory Policies.

2. Promotional Policies.

3. Credit Policies.

4. Representational Policies.

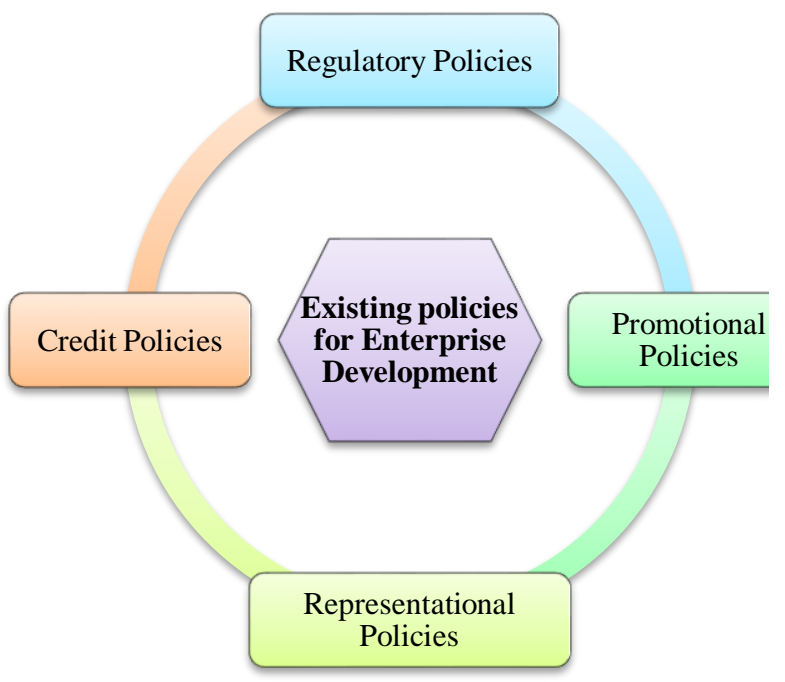

\begin{tabular}{|l|l|l|}
\hline Srl. & $\begin{array}{l}\text { Types } \\
\text { Policies }\end{array}$ & Meaning \\
\hline 1 & $\begin{array}{l}\text { Regulatory } \\
\text { Policies }\end{array}$ & $\begin{array}{l}\text { Ensuring laws compliance for } \\
\text { various aspects of a business } \\
\text { more gender-neutral few } \\
\text { women-specific }\end{array}$ \\
\hline 2 & $\begin{array}{l}\text { Promotional } \\
\text { Policies }\end{array}$ & $\begin{array}{l}\text { Policies for promotion of self- } \\
\text { employment and women- } \\
\text { entrepreneurship }\end{array}$ \\
\hline 3 & $\begin{array}{l}\text { For credit and finance support } \\
\text { Policies }\end{array}$ & $\begin{array}{l}\text { women for business in } \\
\text { selected sectors such as } \\
\text { agriculture and small-scale } \\
\text { industry }\end{array}$ \\
\hline 4 & $\begin{array}{l}\text { These policies } \\
\text { participation of citizen in the } \\
\text { processes of formulation, } \\
\text { implementation } \\
\text { onal Policies } \\
\text { monitoring of policies and } \\
\text { regulations. } \\
\text { This includes four groups: } \\
\text { Producers, traders, workers } \\
\text { and consumers. }\end{array}$ \\
\hline
\end{tabular}

To appraise the benefits offered to women in enterprise development on the following dimensions.

a. Women-specific Policies - which is 100 percent meant for women;

b. Pro-women policies - which incorporate at least 30 percent of the allocation for women only.

c. Gender-neutral policies - meant for the community as a whole (both men and women).

\section{CHALLENGES FOR WOMEN- ENTREPRENEUR IN INDIAN}

i. Male-dominated society

ii. Lack of education

iii. Problem of finance

iv. Low-risk bearing capacity

v. Limited mobility

vi. Legal formalities

vii. Exploitation by middlemen

viii. Not being taken seriously 


\section{International Journal of Engineering Technology and Management Sciences}

Website: ijetms.in Issue: 2 Volume No.5 March - 2021 DOI: 10.46647/ijetms.2021.v05i02.001 ISSN: $2581-4621$

ix. Lack of knowledge regarding the

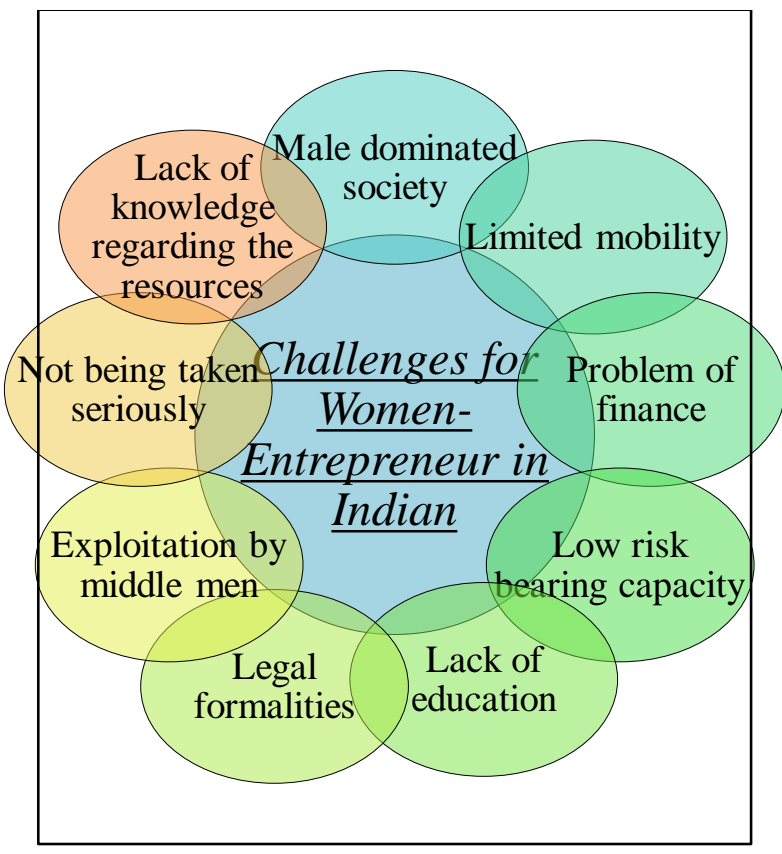

Figure 1: Challenges for Womenentrepreneur in Indian

\section{CONCLUSIONS \& ANALYSIS}

After 70 years of Independence still, India is having is a male dominating society where male member plays a major role in decision making and women are having limited control as well as limited control over resources.

Nowadays women are educated with technical and professional credentials. Most of them have a proficient education. Many entered their family business as equal partners. Women start their nursing homes, boutiques, small manufacturing enterprises, and garment business. Women start the enterprise with their own choices and courage. Though, many have to face family opposition and do not get sufficient support from their families. resources.

\section{Gender disparity and lack of knowledge of existing schemes}

Gender discrimination remains common within Indian society. According to the Human Development Report (UNDP, 2013), India ranks 132th from 186 countries, in the Gender Inequality Index.

Causes for gender inequality in India include high illiteracy level, the lack of decision-making power over childbearing and early marriage of women, which are cause for a low rate in women starting a career and becoming entrepreneurs. There is no shortage in policies and credit schemes, but these do not reach out to prospects however, due to the lack of awareness building mechanisms.

Other challenges and obstacles womenentrepreneurs face 


\section{International Journal of Engineering Technology and Management Sciences}

Website: ijetms.in Issue: 2 Volume No.5 March - 2021 DOI: 10.46647/ijetms.2021.v05i02.001 ISSN: 2581-4621

Availing finance and performing many responsibilities are major hurdles faced by women in initiating and managing an enterprise. Other hindering factors include gender discrimination, lack of information, training opportunities, infrastructure, etc. Some internal factors such as risk aversion by women, and self-confidence, etc. also create a barrier in women's entrepreneurship. Lack of information regarding the availability of raw material, access to finance and Government' schemes and facilities, and other existing or upcoming opportunities.

As per the 2011 census in India, 30 percent of women are illiterate compared with 13 percent of illiteracy among men. In India, mostly women are dependent on their husbands for finance, which reduces their ability to bear the risks involved in launching a business. The male child gets complete ownership over the Parental immovable property (land/building/house) or business in succession. This is one of the reasons women face difficulty in obtaining finance, managing the working capital, and credit. In addition, women entrepreneurs often have to take loans in the names of their husbands, fathers, or brothers, and consequently, by default involve them in the business. Women need to devote a considerable amount of time for their business, if a woman is unable to spend sufficient time with her family, many conflicts may arise. Family member's support, cooperation, or encouragements are most likely to pursue an enterprise.

When it comes to starting-up business, women have traditionally lagged behind men. Women entrepreneurs counter much trouble in different aspects of finance, marketing, and family. After independence, the law guaranteed gender equality to create equal opportunities in education and employment. But, the government-sponsored activities have benefited only a small segment of women. At this stage, efficient steps are needed to provide entrepreneurial awareness, orientation and skill development programs to women. Regeneration of entrepreneurship is the prerequisite at present which is only possible by increasing literacy, spreading knowledge. They should be realized about their strengths and role in society and the contribution they can make in the economy. Women entrepreneurs must be moulded with entrepreneurial traits and skills as per the changing trends, challenges. They should be proficient to sustain and endeavour for superiority in the entrepreneurial field. It also depends on the realization of every resident regarding the imperative role performed by women in society. Only this consciousness can hammer the conservative and rigid thought process in the society which is the largest obstruction in country's growth

\section{KEY RECOMMENDATIONS:}

1. Raise the capability of women to increase the contribution in the labor force by ensuring the availability of affordable child care and equal treatment in the workplace.

2. The creation of government offices for conducting a programme for women for organizing seminars and meetings and information to start and grow a business. 


\section{International Journal of Engineering Technology and Management Sciences}

Website: ijetms.in Issue: 2 Volume No.5 March - 2021 DOI: 10.46647/ijetms.2021.v05i02.001 ISSN: $2581-4621$

3. Promoting the development of national and international women-entrepreneur networks to facilitate entrepreneurial endeavours in a worldwide economy.

4. Frequently evaluating the impact of policies on the accomplishment of women-owned businesses and the

\section{References:}

[1] Ancita (2012 September 01) "Women and Entrepreneurship in India". Retrieved from http://delhi.startupweekend.org/2012/09/0 1/women-and-entrepreneurship-in-india [2] Brush, C. (1992). 'Research of Women Business Owners: Past Trends, a new Perspective, Future Directions, Entrepreneurship Theory and Practice', 16: 5-30.

[3] Devpriya, dey (2014) "The challenging factors for women entrepreneurs in blending family and work". European Academic Research vol. II, Issue 6, September 2014, ISSN 22864822 .

[4] Dubashi, Vinzye Medha. (1987). Women Entrepreneurs in India - A Socio Economic Study of Delhi, pp. 75-85. New Delhi:

[5] Kanitkar, Ajit. (1994). Entrepreneurs and Micro Enterprises in Rural India. Economic and Political Weekly, 29(9).

[6] Ganesamurthy V. S. "India: Economic Empowerment of Women", New Century Publications, New Delhi, pp. 213-221. degree to which businesses take benefit of them.

5. Improve the factual and rational basis of thoughtful to the role of women entrepreneurs in the economy.

[7] Gale A. \& Polnareva L. (2004). 'Women in Management in Russia. in Women in Management Worldwide. Facts, Figures and Analysis'. M. Davidson and R.Burke (eds.), Ashgate, Cornwall.

[8] Gishkori, Z. (2010). 'Against all Odds' The Express Tribune Magazine: Karachi.

[9] Guerrero, V. (2008). 'Women and Leadership: Examining the Impact of Entrepreneurial Education on Leadership Self Efficacy' (Doctoral dissertation, Pepperdine University).

[10] Hisrich, R.D., \& C.G. Brush, (1986). 'The Woman Entrepreneur: Starting, Managing and Financing a Successful New Business' (London, Lexington Books).

[11] Holyquist, C. Carter, S.,(2009). "The Diana Project; Pioneering Women Studying Pioneering Women" Small Business Economics, Springer.

[12] Huq, A., (2009). 'Feasibility of Business Ownership by Educated Urban Women: A Developing Country Perspective'. ICSB World Conference Seoul.

[13] Jalbert E.Susanne, (2000). "Women Entrepreneurs in the Global Economy," Ph. D. March 17, p. 10-11.

[14] Kaushambi (2012, Jun 29) "Women Entrepreneurship in India: On the rise and how" 


\section{International Journal of Engineering Technology and Management Sciences}

Website: ijetms.in Issue: 2 Volume No.5 March - 2021 DOI: 10.46647/ijetms.2021.v05i02.001 ISSN: 2581-4621

http://trak.in/tags/business/2012/06/29/wo men-entrepreneurship-rise-india

[15] Prakash, Goyal (2011) "Women Entrepreneurship in India: Problem and Prospects". International Journal of Multidisciplinary Research Vol.1 Issue 5, September 2011, ISSN 22315780.

[16] Kollan, B., and Parikh, I., (2005). 'A Reflection of the Indian Women in Entrepreneurial World', working paper Indian Institute of Management: Ahmadabad-380 015.

[17] Kumari, Sumitra. (2006). Dynamics of Women Empowerment. New Delhi: Alfa Publications.

[18] latha, a., \& kumar, a. (2015). Entrepreneurship Problems and Prospects in India. International Conference on Contemporary Issues and Challenges of Indian Business in Global Scenario, (pp. 289-294).

[19] Matlay, H., (2005). 'Researching Entrepreneurship, Part 1: What Is Entrepreneurship and does it Matter?' Education and Training, 47, 8/9, 665-677.

[20] Minitti, M. Arenius, P. \& Langowitz, N., (2005). "Global Entrepreneurship Monitor 2004 report on Women and Entrepreneurship" Babson Park, MA: Babson College.

[21] Raj, m. (2014). Women Empowerment through Employment Opportunities in India. International Journal of Management and International Business Studies., 4, 93-100.
[22] Rashid, Che Ngah, Mohamed, Mansor (2015) "Success Factors Among Women Entrepreneur in Malaysia”. International Academic Research, Journal of Business and Technology 1 (2) 2015 Page 28-36, ISSN: 2289-8433.

[23] Sivaram V (2016 Jan).’'Indian women entrepreneurs in startup India: Things are better, but much more needs to change". Retrieved from http://qz.com/596281/indian-womenentrepreneurs-at-startup-india-things-arebetter-butmuch- more-needs-to-change [24] Suri g. (2016). "Is the Startup India Action Plan really that startupfriendly?"

https://yourstory.com/2016/01/startupindia-action-plan-analysis

[25] Shanthi, K., \& Seethalakshmi, K. (1998). Economic Empowerment through Self-Employment. K. Shanthi (Ed) New Delhi:

[26] Venkata, Ravi R. Empowerment of People: Grassroots Strategies and Issues, pp. 1-20. New Delhi: Kanishka Publishers.

[27] Vijayakumar, and jayachitra (2013) "Women Entrepreneurs in India: Emerging issues and challenges". International Journal of Development Research Vol. 3, Issue, 04, pp. 012-017, April, 2013, ISSN: 2230-9926.

[28] Walokar, Deepak. (2001). Women Entrepreneurs. Introduction to Women and Enterprise - A Book Review. Himalaya Publishing House. 